\title{
A Report of Centrocestus formosanus (Nishigori, 1924) (Digenea: Heterophyidae) in Intermediate Host (Fish)
}

\author{
Amit Bharat Gamit*, Pramod Kumar Nanda, Ria Bhar, Samiran Bandyopadhyay and \\ Subhasish Bandyopadhyay
}
Eastern Regional Station, ICAR-Indian Veterinary Research Institute, 37-Belgachia Road, Kolkata-700 037, West Bengal, India

*Corresponding author

\section{A B S T R A C T}

\begin{tabular}{|l|}
\hline Ke y w o r d s \\
Fish, Metacercariae, \\
$\begin{array}{l}\text { Centrocestus } \\
\text { formosanus, } \\
\text { Polymerase chain } \\
\text { reaction }\end{array}$ \\
\hline Article Info \\
\hline $\begin{array}{l}\text { Accepted: } \\
\text { 08 June } 2018 \\
\text { Available Online: } \\
\text { 10 July } 2018\end{array}$ \\
\hline
\end{tabular}

Fish acts as an intermediate host to many helminth parasites, including trematodes of public health significance. In this study, we screened freshwater fish samples $(n=195)$ collected from different markets located in and around Kolkata, to isolate and identify larval stage of minute intestinal fluke, Centrocestus formosanus employing a fast and accurate molecular approach. Processing of fish samples through pepsin digestion method revealed an overall prevalence of $14.87 \%$ infection in fish with encysted metacercariae of trematode, Centrocestus. The prevalence rate was highest in Mystus tengara (40.00\%) followed by Puntius spp. (26.66\%) and Awaous grammepomus (5.26\%), whereas screening fish species such as Labeo bata, Cirrhinus mrigala and Oreochromis niloticus did not harbor any such larval stage of this trematode. Polymerase chain reaction using oligonucleotide primer sets from extracted genomic DNA of these metacercariae revealed amplicon of approx. 492 bp closely resembling to Centrocestus. Phylogenesis showed maximum relationship with the Centrocestus spp. Therefore, implementation of control strategies, apart from awareness of public and adoption of good aquaculture practices by farmers, are required in order to minimize the risk of infection in fish.

\section{Introduction}

There are numerous minute intestinal flukes belonging to the family Heterophyidae. Centrocestus formosanus (Nishigori, 1924) is one among them inhabiting the small intestine of fish eating birds and mammals, including chickens, ducklings, dogs, cats, foxes, mice, rats and rabbits. This trematode is considered as an Asian species but it has been introduced around the world and distributed in many countries including Taiwan, China, Japan,
Thailand, Hawaii, Vietnam, Croatia, India, USA, Mexico, and Colombia (Srisawangwong et al., 1997; Mitchell et al., 2005; SalgadoMaldonado et al., 2005; Velasquez et al., 2006; Gjurcevic et al., 2007).

It is digenean that requires two intermediate hosts and one definitive host to complete the life cycle. Red rimmed thiarid snail, Melanoides tuberculatus act as first intermediate host and many fish species, harbouring metacercariae, have been reported 
as a second intermediate host. Metacercariae localize into the gills and sometimes under the scales of numerous fish species and finally infects the fish eating animals and birds. This trematode not only causes significant morbidity but is often associated with food safety and quality problems in fish ( $\mathrm{Yu}$ and Mott, 1994; Toledo et al., 2006). Infected fish can develop serious pathologies of gills including oedema, haemorrhage and loss of respiratory epithelium and cause serious weakness and sometimes mortality in case of heavy infection. Furthermore, these trematodes can potentially infect humans as reported from many countries of Asia including Taiwan, Japan and Lao PDR (Nishigori, 1924; Waikagul et al., 1997; Chai et al., 2013) through consumption of raw or improperly cooked fish containing metacercariae.

The detection of Centrocestus infection relies on the microscopic observation of eggs in the faeces of infected definitive host (animal or human). However, accurate diagnosis with microscopy is not always possible due to similar morphology with the eggs of other heterophyids and opisthorchiids. Identification of metacercariae at species level is also difficult due to similar morphology with other Centrocestus metacercariae. To overcome such problems, molecular approaches through amplification and sequencing of some conserved DNA regions, especially utilizing genetic markers in nuclear ribosomal DNA (rDNA) and mitochondrial DNA are often employed to diagnose helminth parasites (Blair et al., 1996). The spacer regions of rDNA (ITS1 and ITS2) are particularly useful in the diagnosis of metazoan parasites at the species level (Morgan and Blair, 1995; LeonRegagnon et al., 1999; Nolan and Cribb, 2005).

As freshwater fish act as second intermediate host, cultured or farmed fish harbouring infective metacercariae of trematode is a concern for human health (WHO, 1995; Howgate, 1998). Fish borne zoonotic trematodes are mostly prevalent in East Asian countries due to traditional aquaculture and feeding habits, but many reports are available from different parts of the world. Although this trematode is a species with pisciculture as well as medical importance, hardly any report is available on identification of this trematode through molecular means. Considering the public health importance of fish borne zoonoses and to assure and accurate diagnosis overcoming the deficiencies of microscopic examination, the present study was conducted to identify $C$. formosanus in fish, the second intermediate host, employing both standard and molecular (PCR) methods which could be useful to demonstrate its epidemiological situation and develop strategies so as to formulate and implement control programs.

\section{Materials and Methods}

\section{Isolation of metacercariae}

For this study, commercially important freshwater fish $(\mathrm{n}=195)$ of six different species (Mystus tengara, Labeo bata, Cirrhinus mrigala, Puntius spp., Awaous grammepomus and Oreochromis niloticus) were collected from nine different fish markets located in and around Kolkata. As per the history, all the samples were from fish farms with traditional culture methods. Following collection, fish species were placed in ice box and transported to the laboratory for further processing. After thorough washing under distilled water, all fish were measured and weighed. The metacercariae were isolated employing the standard pepsin digestion method. Briefly, the finely ground fish were digested by artificial digestion solution containing $0.5 \%$ pepsin $(1: 10,000$, Hi-Media, India) and $1 \% \mathrm{HCl}(\mathrm{Hi}-$ Media, India) and incubated for 2-3 hrs at $37^{\circ}$ $\mathrm{C}$ with occasional shaking. Digestion was 
followed by straining and sedimentation repeated for 7-8 times using solution of $0.85 \%$ saline, until the supernatant became clear. The metacercariae were isolated from the bottom sediment and the rate of prevalence and intensity of infection were calculated out. The isolated metacercariae were examined under stereomicroscope and microscope for identifying the morphological features including shape and size of cyst, circumoral spines and shape of excretory bladder using the morphological criteria (Chai et al., 2012) and stored in $70 \%$ ethanol at $-20^{\circ} \mathrm{C}$ until DNA extraction.

\section{Total genomic DNA extraction}

Genomic DNA extraction was done separately from all the isolated metacercarial samples using GF-1 Tissue Extraction Kit (Vivantis, Malaysia) according to the manufacturer's instructions. DNA was eluted in 70-100 $\mu$ l of elution buffer and stored at $-20^{\circ} \mathrm{C}$ until further use. The integrity of DNA was checked by $1 \%$ agarose gel electrophoresis in $0.5 \mathrm{X}$ TAE buffer. A $2 \mu l$ of genomic DNA was loaded in the gel after proper mixing with $6 \mathrm{X}$ loading dye (Thermo Scientific, USA) and gel was run at $70 \mathrm{~V}$ for $1 \mathrm{hr}$ and visualized under ultraviolet light in a Wealtech apparatus (Wealtech, USA).

Primer design, PCR amplification and sequencing

In this study, we selected published primer set (Van et al., 2009) for amplification of complete ITS2 segment of ribosomal DNA of Centrocestus spp. using genomic DNA extracted from the metacercariae. All the extracted DNA samples were used separately as a template for amplification. Primers used were 5'-GGT ACC GGT GGA TCA CTC GGC TCG TG -3' (F) as a forward primer and 5'- TAT GCT TAA ATT CAG CGG GT -3' $(\mathrm{R})$ as a reverse primer.
The PCR reaction was carried out in $25 \mu 1$ volume with 8-10 pmol of each primers from Xcelris genomics (Ahmedabad, India), 1unit of Taq DNA polymerase (Thermo Scientific, USA), 10x Taq buffer with $\mathrm{KCl}$ (Thermo Scientific, USA), dNTPs mix $(10 \mathrm{mM}$, Thermo Scientific, USA). PCR was performed by initial denaturation at $94^{\circ} \mathrm{C}$ temperature for $2 \mathrm{~min}$, followed by 35 cycles each at $95^{\circ} \mathrm{C}$ for $30 \mathrm{sec}, 50^{\circ} \mathrm{C}$ for $30 \mathrm{sec}$ and $72^{\circ} \mathrm{C}$ for $2 \mathrm{~min}$ and final extension at $72^{\circ} \mathrm{C}$ for $7 \mathrm{~min}$. The amplified PCR products were separated by electrophoresis through $1 \%(\mathrm{w} / \mathrm{v})$ agarose gel in TAE buffer and visualized as described earlier. For DNA sequencing, amplified PCR products were purified using gel purification kit (Sigma-Aldrich, USA) according to the manufacturer's instructions and sequenced in both forward and reverse directions using PCR primers on an automated sequencer by DNA sequencing services of Scigenom labs, Kerala, India.

\section{Sequence analysis and phylogenic tree reconstruction}

The DNA sequences were further analyzed using basic local alignment search tool (BLAST; http://blast.ncbi.nlm.nih.gov/Blast. cgi) to check the homology with published sequence databases. Phylogenic tree reconstruction was carried out by MEGA software version 7.0 using published ITS2 sequences of Centrocestus and other related heterophyids available in the Genbank databases by maximum likelihood (ML) as well as neighborhood joining (NJ) method (Table 1).

\section{Results and Discussion}

Overall 29 of the 195 samples and 3 of the 6 fish species were found infected with the Centrocestus metacercariae. The range of metacercariae varied from 20-60 per processed sample. Metacercariae were 
detected only in three freshwater fish species viz. M. tengara, Puntius spp. and A. grammepomus. No metacercariae was detected in other fish species screened such as L. bata, C. mrigala and O. niloticus. The fresh water fish species, M. tengara and Puntius spp. were found to be infected in almost all markets surveyed in this study. The prevalence rate was highest in $M$. tengara 40.00\% followed by Puntius spp. $26.66 \%$ and A. grammepomus $5.26 \%$ (Table 2).

The metacercariae of Centrocestus were elliptical, had approx. 32 circumoral spines around the oral sucker arranged in 2 rows, and an X-shaped excretory bladder with dark granules inside. These characters were identical with the findings of Chai et al (2012). PCR amplification result showed clear amplicon of approx. 492bp in almost all DNA samples of metacercariae (Figure 1). BLAST result showed the maximum homology (99\%) with the Centrocestus isolate from Thailand. The obtained sequence was submitted to the NCBI (KT020834.1). In phylogenesis, both character and distance methods showed maximum relationship with the Centrocestus spp. (Figure 2 and 3).

Table.1 Published Internal Transcribed Spacer 2 sequences used for Phylogenetic tree reconstruction

\begin{tabular}{|c|c|c|c|}
\hline Sl.No. & Species & Country & Accession No. \\
\hline 1 & Centrocestus sp. & India & $\begin{array}{c}\text { KT020834 } \\
\text { (obtained sequence) }\end{array}$ \\
\hline 2 & Centrocestus sp. RD-2003 & Israel & AY245699.1 \\
\hline 3 & $\begin{array}{l}\text { Centrocestus sp. PWK-2013 } \\
\text { isolate }\end{array}$ & Denmark & KF658456.1 \\
\hline 4 & Centrocestus sp. TC-2014 & Thailand & KJ630836.1 \\
\hline 5 & $\begin{array}{l}\text { Centrocestus sp. PWK-2013 } \\
\text { isolate }\end{array}$ & Denmark & KF658455.1 \\
\hline 6 & $\begin{array}{l}\text { Centrocestus sp. MK-2012 } \\
\text { isolate C1 }\end{array}$ & Iran & JQ390545.1 \\
\hline 7 & $\begin{array}{l}\text { Centrocestus sp. MK-2012 } \\
\text { isolate C } 3\end{array}$ & Iran & JQ390547.1 \\
\hline 8 & Haplorchis taichui & Thailand & KJ630831.1 \\
\hline 9 & Haplorchis pumilio & China & KP165437.1 \\
\hline
\end{tabular}

Table.2 Infection status of examined fish samples with Centrocestus metacercariae

\begin{tabular}{|c|l|c|c|c|c|c|}
\hline $\begin{array}{c}\text { Sl. } \\
\text { No. }\end{array}$ & \multicolumn{1}{|c|}{ Fish species } & $\begin{array}{c}\text { Samples } \\
\text { examined }\end{array}$ & $\begin{array}{c}\text { Infected } \\
\text { samples }\end{array}$ & $\begin{array}{c}\text { Prevalence } \\
(\%)\end{array}$ & $\begin{array}{c}\text { Range of } \\
\text { metacercariae }\end{array}$ & $\begin{array}{c}\text { Intens } \\
\text { ity }\end{array}$ \\
\hline $\mathbf{1}$ & Puntius spp. & 60 & 16 & 26.66 & $20-40$ & 30 \\
\hline $\mathbf{2}$ & Labeo bata & 22 & 00 & 00.00 & 0 & 00 \\
\hline $\mathbf{3}$ & Cirrhinus mrigala & 33 & 00 & 00.00 & 0 & 00 \\
\hline $\mathbf{4}$ & Mystus tengara & 30 & 12 & 40.00 & $30-60$ & 45 \\
\hline $\mathbf{5}$ & Oreochromis niloticus & 31 & 00 & 00.00 & 0 & 00 \\
\hline $\mathbf{6}$ & Awaous grammepomus & 19 & 01 & 05.26 & 22 & 22 \\
\hline & Total & $\mathbf{1 9 5}$ & $\mathbf{2 9}$ & $\mathbf{1 4 . 8 7}$ & $\mathbf{2 0 - 6 0}$ & \\
\hline
\end{tabular}


Fig.1 PCR amplification of ITS2 segment of rDNA. The samples were analyzed by 1\% Agarose gel electrophoresis stained by Ethidium bromide dye. Lane M: DNA Marker (100bp DNA ladder). Lane $1 \&$ 2: DNA sample of metacercariae. N: Negative control

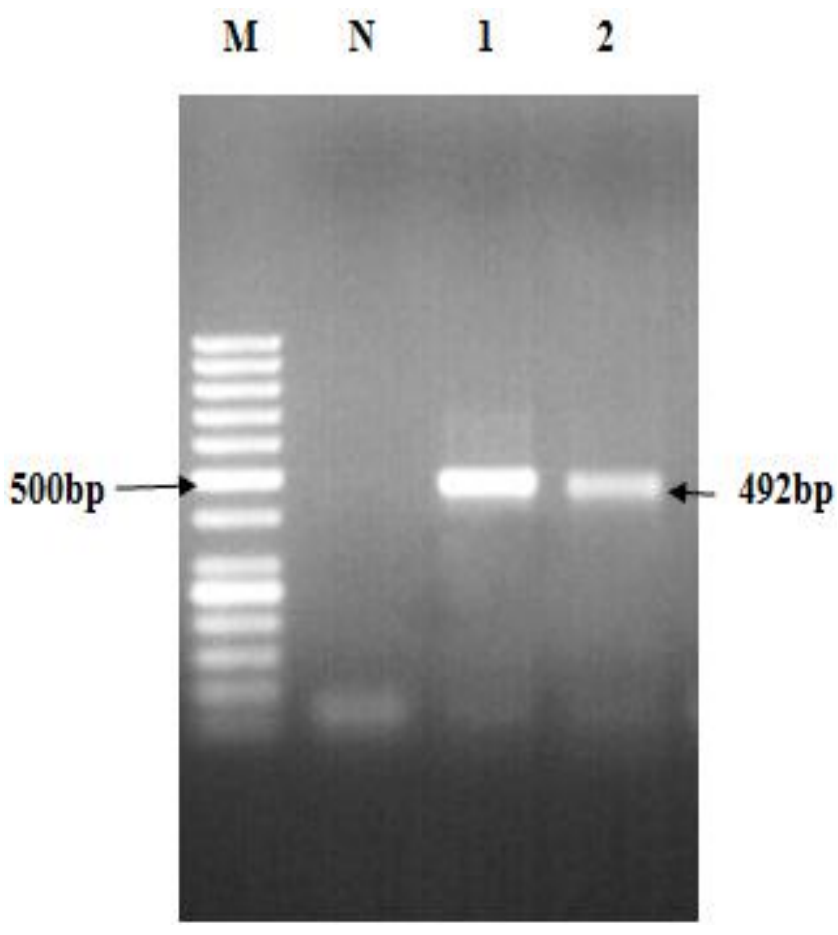

Fig.2 Phylogenetic tree reconstruction by MEGA7 software using the maximum likelihood algorithm

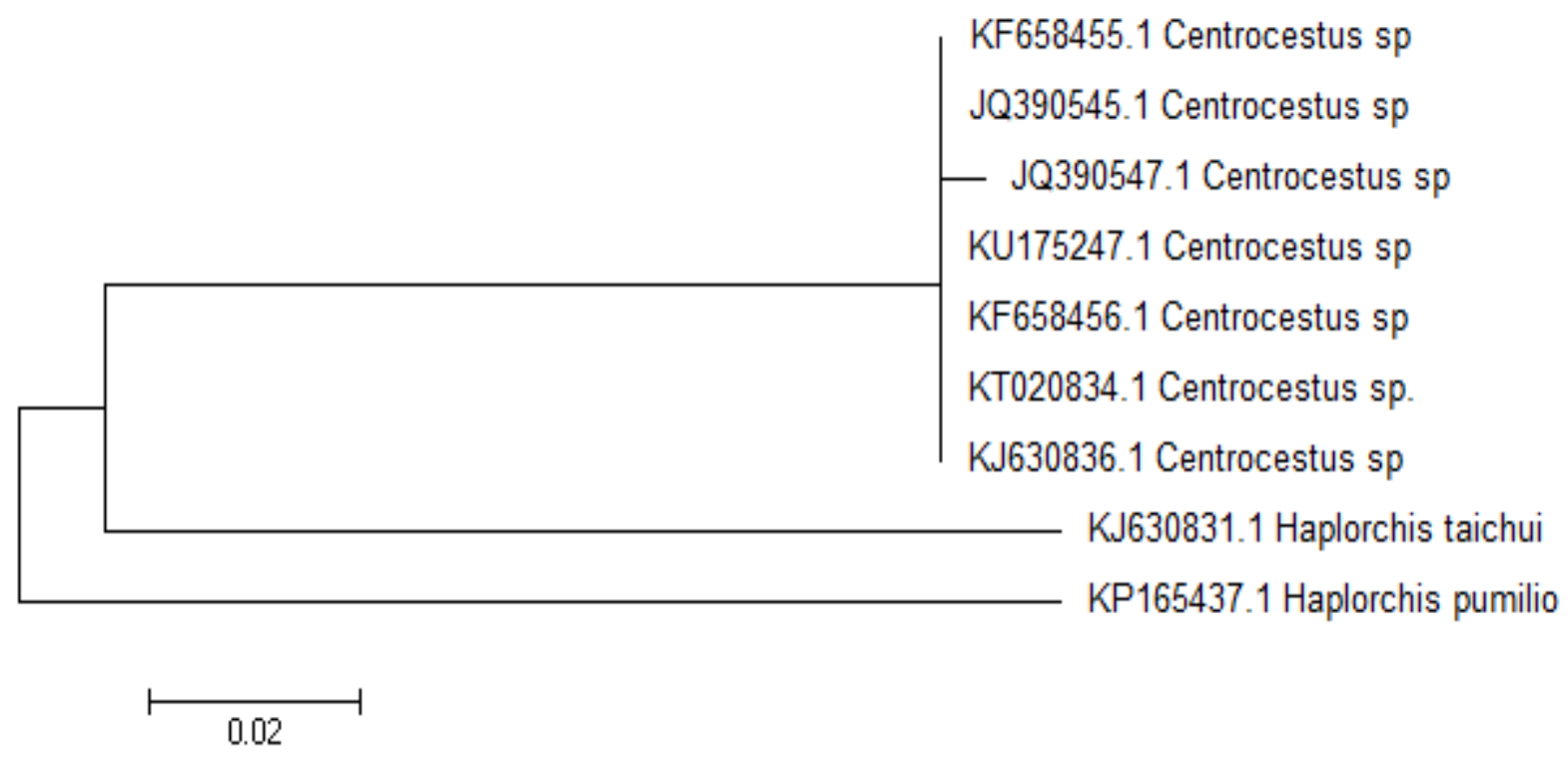


Fig.3 Phylogenetic tree reconstruction by MEGA7 software using the Neighbor-Joining algorithm

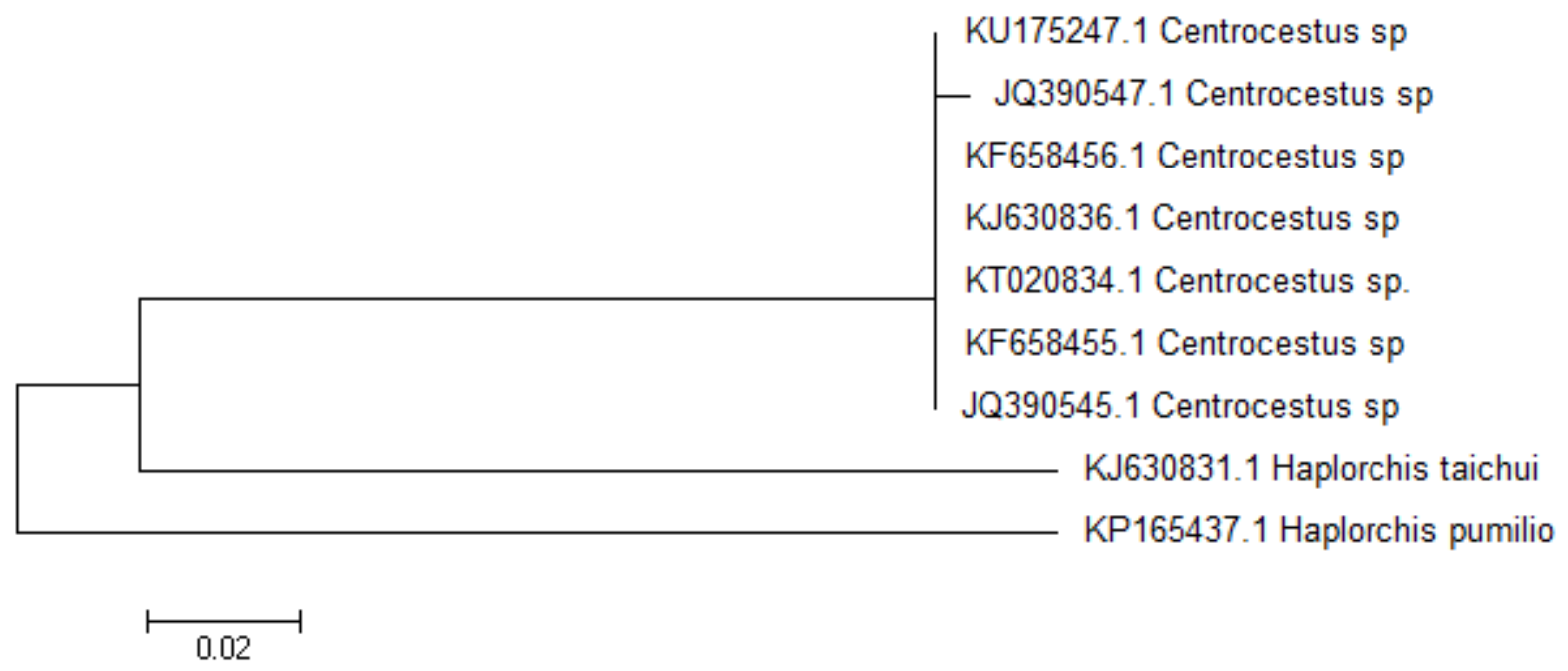

In the study, we screened six different freshwater fish species of nine different markets to isolate metacercariae of Centrocestus spp. using artificial pepsin digestion technique. The overall prevalence rate of encysted metacercariae in fish was $14.87 \%$ and three fish species viz., Puntius spp. M. tengara and A. grammepomus were found to be infected. However, the rate of prevalence and intensity of infection of metacercariae in different fish species varied and ranged from $5.26 \%-40.00 \%$ and 20-60, respectively.

Prevalence (proportion infected) and mean intensity (parasites per infected individual) are population-level descriptors of parasite abundance (Bush, 1997). Different workers have reported the prevalence report of encysted metacercariae of Centrocestus differently in different fish species. A study reported prevalence $(31.1 \%)$ and mean intensity of infection (3.42) in fingerlings of $O$. niloticus collected from an artificial urban lake from Belo Horizonte, Minas Gerais, Brazil (Pinto et al., 2014). A study conducted in central Texas by Fleming et al (2011) revealed 14 of the 25 species examined $(56.0 \%)$ and $171(27.1 \%)$ of the individual fish infected with $C$. formosanus metacercariae. A survey in Phnom Penh and Pursat Province, Cambodia by Chai et al (2014) reported $10.0 \%$ infection status of freshwater fish with $C$. formosanus metacercariae. Available reports from the literature also indicate a variable intensity of infection by Centrocestus spp. in different fish species ranging from 1 to 5,935 metacercariae (Scholz and SalgadoMaldonado, 2000; Chen, 1942). The variation in prevalence and intensity of infection may be due to inter-species differences between fish species, difference in age, size and availability of the intermediate hosts, ecological factors and environmental conditions of the water (Srisawangwong et al., 1997; Pinto et al., 2014; Chai, 2007).

Identification of Centrocestus in the definitive host is difficult with conventional methods due to almost similar morphology to other heterophyids. The identification and confirmation of metacercariae in fish up to species level is also problematic due to overlapping of spines (Chai et al., 2012). To overcome the problem, traditional diagnostic techniques in parasitology are now complemented by a variety of PCR-based 
molecular tools to resolve the taxonomic issues on the basis of phenotypic characteristics (Thompson 2004). Moreover, internal transcribed spacers (ITS1 and ITS2) have frequently been used as molecular markers for differentiating closely-related food-borne trematode species, as a high level of inter-species sequence divergence exists among them (Sato et al., 2009; Traub et al., 2009).

Therefore, we applied a molecular approach to identify the metacercariae of $C$. formosanus in the second intermediate host, fish. For molecular level confirmation of the species, genomic DNA was extracted and ITS2 segments of rDNA were amplified. The amplified products were confirmed as nucleotide sequences of Centrocestus by sequencing. The sequence analysis showed 99\% homology with other published sequences of Centrocestus from different countries.

The study provides an approach for detection of infective stage (metacercariae) of $C$. formosanus in its second intermediate host, fish. Although the zoonotic importance of this fluke is unknown, but few human cases have been reported in countries other than India (Waikagul et al., 1997; Chai et al., 2013). Nevertheless, the fish species viz., Puntius spp., $M$. tengara and $A$. grammeротиs found harbouring infective metacercariae of Centrocestus in this study are mostly consumed by the people as a daily diet in the eastern region of India, including Kolkata, West Bengal. Furthermore, animals consuming the byproducts of fishes can act as a reservoir hosts and may spread infection in the environment even without the involvement of human host. Therefore, implementation of control strategies, apart from awareness of public and adoption of good aquaculture practice by farmers, are required in order to minimize the risk of trematode infection in fish. Besides, further research involving reservoir hosts and first intermediate host (snail species) need to be carried out to get a complete picture of the life cycle of this trematode in order to identify and implement control measures at transmission site level.

\section{Acknowledgements}

The authors express sincere thanks to the Director and Joint Director (Research), ICAR-Indian Veterinary Research Institute, Izatnagar, Bareilly, India for providing necessary facilities to conduct the study.

\section{Competing interests}

The authors declare that they have no competing interests.

\section{References}

Blair, D., Campos, A., Cummings, M.P. and Laclette, J.P. 1996. Evolutionary biology of parasitic platyhelminths: the role of molecular phylogenetics. Parasitol. Today, 12: 66-71.

Bush, A.O., Lafferty, K.D., Lotz, J.M. and Shostak, A.W. 1997. Parasitology meets ecology on its own terms: Margolis et al., revisited. J. Parasitol., 83: 575-583.

Chai, J.Y., Nguyen, V.D. and Woon-Mok, S. 2012. Foodborne trematode metacercariae in fish from Northern Vietnam and their adults recovered from experimental hamsters. Korean J. Parasitol., 50: 317-325.

Chai, J.Y., Sohn, W.M., Yong, T.S., Eom, K.S., Min, D.Y., Lee, M.Y., Lim, H., Insisiengmay, B., Phommasack, B. and Rim, H.J. 2013. Centrocestus formosanus (Heterophyidae): Human infections and the infection source in Lao PDR. J. Parasitol., 99:531-536. 
Chai, J.Y., Sohn, W.M., Na, B.K., Yong, T.S., Eom, K.S., Yoon, C.H., Hoang, E.H., Jeoung, H.G. and Socheat, D. 2014. Zoonotic trematode metacercariae in fish from Phnom Penh and Pursat, Cambodia. Korean J. Parasitol., 52: 35-40.

Chai, J.Y. 2007. Intestinal Flukes. In: Foodborne Parasitic Zoonoses: Fish and Plant-borne Parasites, World Class Parasites, Murrell, K.D.; Fried, B., Eds.; Springer, New York, USA.11,pp. 53-115.

Chen, H.T. 1942. The metacercaria and adult of Centrocestus formosanus (Nishigori, 1924), with notes on the natural infection of rats and cats with C. armatus (Tanabe, 1922). J. Parasitol., 28: 285-298.

Fleming, B.P., Huffman, D.G., Bonner, T.H. and Brandt, T.M. 2011. Metacercarial distribution of Centrocestus formosanus among fish hosts in the Guadalupe River drainage of Texas. J. Aquat. Anim. Health., 23: 117-124.

Gjurcevic, E., Petrinec, Z., Kozaric, Z., Kuzir, S., Gjurcevic, K.V., Vucemilo, M. and Dzaja, P. 2007. Metacercariae of Centrocestus formosanus in goldfish (Carassius auratus L.) imported into Croatia. Helminthologia., 44:214-216.

Howgate, P. 1998. Review of the public health safety of products from aquaculture. Int. J. Food Sci. Tech., 33: 99-125.

Leon-Regagnon, V. Brooks, D.R. and PerezPonce, de L.G. 1999. Differentiation of Mexican species of Haematoloechus looss, 1899 (Digenea: Plagiorchiformes): molecular and morphological evidence. J. Parasitol., 85: 935-946.

Mitchell, A.J., Overstreet, R.M. Goodwin, A.E. and Brandt, T.M. 2005. Spread of an exotic fish-gill trematode. Fisheries., 30:11-16.
Morgan, J.A.T. and Blair, D. 1995. Nuclear rDNA ITS sequence variation in the trematode genus Echinostoma: an aid to establishing relationships within the 37-collar spine group. Parasitol., 111: 609-615.

Nishigori, M. 1924. On a new trematode Stamnosoma formosanumn. sp. and its development. Taiwan Igakkai Zasshi., 234:181-228.

Nolan, M.J. and Cribb, T.H. 2005. The use and implications of ribosomal DNA sequencing for the discrimination of digenean species. Adv. Parasitol., 60: 102-163.

Pinto, H.A., Mati, V.L.T. and Melo, A.L. 2014. Metacercarial Infection of wild Nile Tilapia (Oreochromis niloticus) from Brazil. Sci. World.,1-7.

Salgado-Maldonado, G., Aguilar-Aguilar, R., Cabanas-Carranza, G., Soto-Galera, E. and Mendoza-Palmero. 2005. Helminth parasites in freshwater fish from the Papaloapan river basin, Mexico. Parasitol. Res., 96:69-89.

Sato, M., Thaenkham, U., Dekumyoy, P. and Waikagul, J. 2009. Discrimination of $O$. viverrini, $C$. sinensis, $H$. pumilio and $H$. taichui using nuclear DNAbased PCR targeting ribosomal DNA ITS regions. Acta Tropica., 109: 8183.

Scholz, T. and Salgado-Maldonado, G. 2000. The introduction and dispersal of Centrocestus formosanus (Nishigori, 1924) (Digenea: Heterophyidae) in Mexico: a review. Am. Midl. Nat., 143:185-200.

Srisawangwong, T., Pinlaor, S., Kanla, P. and Sithithaworn, P. 1997. Centrocestus formosanus: surface morphology of metacercaria, adult and egg. J. Helminthol., 71:345-350.

Thompson, R.C. 2004. The zoonotic significance and molecular epidemiology of Giardia and 
giardiasis. Vet. Parasitol., 126: 15-35.

Toledo, R., Esteban, J.G. and Fried, B. 2006. Immunology and pathology of intestinal trematodes in their definitive hosts. Adv. Parasitol., 63:285-365.

Traub, R.J., Macaranas, J., Mungthin, M., Leelayoova, S., Cribb, T., Murrel, K.D. and Thompson, R.C.A. 2009. A new PCR-based approach indicates the range of Clonorchis sinensis now extends to Central Thailand. PLoS Negl. Trop. Dis., 3: e367.

Van, K., Van, A.D., Blair, D. and Le, T.H. 2009. Haplorchis pumilio and $H$. taichui in Vietnam discriminated using ITS-2 DNA sequence data from adults and larvae. Exp. Parasitol., 123: 146-151.

Velasquez, L.E., Bedoya, J.C., Areiza, A. and
Valez, I. 2006. First record of Centrocestus formosanus (Digenea: Heterophyidae) in Colombia. Rev. Mex. Biodivers., 77:119-121.

Waikagul, J., Wongsaroj, T., Radomyos, P., Meesomboon, V., Praewanich, R. and Jongsuksuntikul, P. 1997. Human infection of Centrocestus caninus in Thailand. Southeast Asian J. Trop. Med. Public Health., 28:831-835.

WHO. 1995. Control of foodborne trematode infections. World Health Organization (WHO) Technical Report Series Geneva., pp. 1-157.

Yu, S.H. and Mott, K.E. 1994. Epidemiology and morbidity of food-borne intestinal trematode infections. Report of World Health Organization (WHO) Geneva., pp: 1-26.

\section{How to cite this article:}

Amit Bharat Gamit, Pramod Kumar Nanda, Ria Bhar, Samiran Bandyopadhyay and Subhasish Bandyopadhyay. 2018. A Report of Centrocestus formosanus (Nishigori, 1924) (Digenea: Heterophyidae) in Intermediate Host (Fish). Int.J.Curr.Microbiol.App.Sci. 7(07): 928-936. doi: https://doi.org/10.20546/ijcmas.2018.707.112 